\title{
How Project Based Learning Boost Learning Environment
}

\author{
Pujiriyanto \\ The Faculty of Teacher Training and Education \\ Sebelas Maret University \\ Surakarta, Indonesia \\ e-mail: pujiriyanto@student.uns.ac.id

\section{Samsi Haryanto} \\ The Faculty of Teacher Training and Education \\ Sebelas Maret University \\ Surakarta, Indonesia \\ e-mail: samai@fkip.uns.ac.id
}

\author{
Mulyoto \\ The Faculty of Teacher Training and Education \\ Sebelas Maret University \\ Surakarta, Indonesia \\ mulyoto@fkip.uns.ac.id
}

\author{
Dewi Rochsantiningsih \\ The Faculty of Teacher Training and Education \\ Sebelas Maret University \\ Surakarta, Indonesia \\ dewi_roch@staff.uns.ac.id
}

\begin{abstract}
Environment is one of the contributing factors to develop creativity. This study aimed to investigate the performance of the project-based learning (PBL) model designed to develop creative learning environments according to the students' perceptions. The method employed for the study is quasi experimental using one group pretest posttest design inlvolved 42 students of an entrepreneurship class. A scale was developed to measure the students' perceptions of learning environment after the treatment. We also observed the students' activities and responses during the project implementation. Paired sample t-test used to analyze the difference between two sets of observation. The result showed that there is significant difference between the two sets of observation. Students' responses indicated that $\mathrm{PBL}$ was capable to develop supporting learning environment that it is useful for creativity development.
\end{abstract}

Keywords-learning environment, project base learning, creativity

\section{INTRODUCTION}

President Jokowi separated the affairs of the Creative Economy from the Ministry of Tourism. He also established a new agency called creative economy institution (Bekraf) dealing with creative economy development in order to promote the creative industries in the country. Universities in Indonesia including whose field of study are education also respond to the policy by strengthening their role through entrepreneurship education. There is awareness among universities' stake holder that the essence of entrepreneurship education is creativity development. There are evidences that academically educated entrepreneurs are more important in developing regional economies than entrepreneurs with a lower level of education [1]. Many universities place entrepreneurship as compulsory subject eventhough it is a relatively new subject. Unfortunately, entrepreneurship education is still taught teoritically and it is still focus on mastery of learning material so pedagogical aspect is becoming imperative challenge. There are many debates which are still going on about the relevance, pedagogies, effectiveness, even about the sense of entrepreneurship education in general [2]. There are numerous challenges faced by entrepreneurship educators to enhance learning based on their experiences which offers many activities [3].

Creativity requires a condusive environment related to psychological security and psychological freedom. Developing creativity can not be achieved without appropriate learning approach which is capable to create more condusive learning environment. Pedagogical models are being applied should be compatible with efforts to form environment that stimulate creativity. [4] stated that learning environment is a factor which is efficient instrument to develop creativity. [5] stated environmental or cultural factors affect to behavior or personality of an entrepreneur greatly.

We found there are two opposite groups related to pedagogical models being applied in entrepreneurship education. The advocates of the conventional pattern and innovators claimed that their own models are the best. The innovators strive to implement the student-centered learning (SCL) approach because it is considered to provide opportunity for improving creativity, such as project-based learning (PBL) is being developed. Many universities are trying to adopt project-based learning as an innovative learning method however PBL is still openly interpreted. The innovators believe that they will get more flexible learning process that accommodate students' characteristic. Unfortunately, the group of innovators often interpret that PBL is very open so it is still far from a systematic instructional design. The innovators convince that the full 
freedom through PBL is able to stimulate students to be more creative. Innovators look to be more radical that focused on final product but less attention in learning environment.

The conventional supporters tend to focus on the mastery of learning material and final product but insufficient attention to environmental factors. Educational institutions need to change the process of learning to enable their students to develop their right brain [6]. [7] indicated a low level of satisfaction with the learning of entrepreneurship conducted for the reason that the learning methods do not capable or insufficient to support conducive learning environment to develop creativity.

The advocates of the conventional pattern come into the judgement that PBL only waste time and causes an uncontrolled learning atmosphere with no clear results. On the other hand, the innovators come into the judgement that the conventional learning pattern is regarded as hampering and shackling so that it causes the learning environment becomes insufficiently to develop students' creativity.

Project-based learning is an instructional method centred on the learner. Students develop a question and guided through research under the teacher's supervision [8]. Projectbased learning can be defined briefly as "a model that organizes learning around projects", involves students in a constructive investigation, focus on problems, drive students into deep learning, and realistic projects [9].

Individuals creativity ability is inseparable from the influence of culture and society. Family is also influential factor that form creative stimulating environment. The attributes that can improve creativity are not only campus environment but also influenced by family [10]. Democratic family is good for developing creativity [11]. The environmental factors are very widespread concept as seen from the macro-perspective include the natural environment and the social environment, besides the personality factor also operating within oneself as self-environment ([12]. Yang \& Zhong, 2012). It indicate that person and environment is related each other. So, the person-environment relation (P-E fit) is important to become congruent. The consideration concerning the person-environment being well matched is based on a tradition about interaction in the field of psychology declaring that individuals' behavior is a function of their characteristics and the environment where they do their activities [13]. The person-environment relation becomes compatible when individuals' perception is well matched with the characteristics of the work environments are desired [14]. Person-environment naturally influence to each other of being reciprocally [15] [12]. [16] stated that "press refers to the relationship of human beings and their environment." Press influences may be general, and perhaps operate through implicit valuation and tradition (cultural, organizational, or familial presses), or more specific (as would be the case in interpersonal exchanges or environmental settings).

The campus environment may be more general and classroom learning environment can be more spesific.
Classrooms' environment can be designed to be more conducive to develop creativity because theories about organizational creativity emphasize the influence of the work environment role on the creative behavior of an individual or a team [17] [18]. According to [19] creativity in a product is a result of a syndrome involving the attributes of the environment both for creators and assessors, including the following; source of evaluation, source of support or resources, and source of stimulation or inspiration.

The most effective strategy for developing creative learning environment is change way of teaching. Strategies that could form condusive learning environment have the characteristics of facilitating active learning, being constructivist and collaborative, and providing opportunities for improvisation [20]. The pedagogical challenge is that entrepreneurial competencies are more holistic and psychologically oriented than traditional subject-matter skills [1].

PBL is characterized by collaboration where learners have opportunity to share their ideas through brainstorming. Students are exposed to a wide range of skills and competencies such as collaboration, project planning, decision making, and time management through project-based learning [21], project-based learning allows in-depth investigation of a topic. In PBL students are central role in design, decision making, and problem-solving based on challenging questions that encouraged students having opportunity to work relatively autonomously [22]. In PBL, students is designed to engage as investigator of complex and authentic problems, then designed products and task carefully [23]. During the investigation students gather information by themselves. Classroom activities should be student-centred, cooperative, and interactive [24]. Students are able to become responsible for their own learning.

[25] stated creativity techniques like brainstorming are generally considered useful tools to generate idea. These characteristics fit the principles of PBL but they need to be designed systematically. Knowledge is constructed by students, but a learning scenario must be designed. PBL are not be worthy of being interpreted very openly. Moderate contructivism is appropriate as the basis for project-based learning. The implementation of PBL rests on students actively learning by doing [26] or using the active learning techniques ([27]. Creative behavior almost can be predicted by the individual's characteristic of, among others, desiring a creative atmosphere. Satisfaction with the context is considerably influenced by environmental characteristics [28]. Many instructors adopt PBL to develop learning achievement and provide a learning environment that draws learners' involvement [29]. A conducive work environment would be perceived by the individual and giving satisfaction is a moderator variable of creativity development [13].

There are research studies that explain the advantages of using project-based learning and its principles in educational settings [30] [31] [32] [33] [34]. However, only a few of them 
have focused on project-based learning in developing learning environment for creativity. [35] gathered information over the past years found the evidence that project-based learning appears to be effective model for producing gains in academic achievement. Project-based learning is still in the developmental stage and there is no empirical data to be able to state certainty that project-based learning is a proven alternative to other forms of learning. These studies on project-based learning were lack of evidence carried out in higher education setting and focus on learning environment for entrepreneurship education setting. From this perspective, this research can be declared to have a significant value. It is hoped that this empirical study can provide a close link between project-based learning and learning environment to stimulate students' creativity, at the same time propose guidelines for lecturers to implement project-based learning.

According to [36] PBL allows learners to identify and formulate their own problems but the goals they set as well as the unexpected discoveries that they will make during their interaction with the environment serve as guides. Based on this argument we conclude that learning environment occurred during the PBL implementation being reciprocally interact with individuals and will be perceived as satisfactory context or not. The need for the investigation of project-based learning in entrepreneurship education was mainly the result of the many demands and curiousity from interested leturers and higher education institution. This paper attempt to explore about the effectiveness of a systematically designed PBL model in increasing learning environment which supports creativity.

PBL was designed to provide stimuli to provoke, enhance, and promote creative processes and products but, considering to [37] that there are some disruptions can promote creativity, other types can disrupt the sense of immersion in the creative task. So, in this research the concept of a creative learning environment is a condition when people feel comfortable or not in expressing their ideas and when constructive support is given in the development and analysis of those ideas. The degree of comfortable depends on students' perception. Thus, researchers developed a scale that enable students can give assessment about the learning environment as a context of creativity development. It was measured according to the students experience had after attending the learning activity. We also noted and observed the students' behavior and respond during the project to describe naturally learning environment that occurred. The questions addressed in this study was as follows; is there a significant mean difference between two sets of observation on learning environment in terms of the usage of project-based learning?

The learning environment was measured based on students' perception in the following aspects; involvement and participation in the learning conducted, the pattern of lecturer interaction, freedom in exploration, participation and collaboration, openness of lecturer attitude, and freedom in executing initiatives.

\section{METHODS}

\section{A. Participant}

The researchers used the quasi-experimental design as approach [38], applying one group pretest-posttest design. Researcher used a class as experimental group that implemented a systematically designed of PBL. The subjects of the study consisted of 42 college students who participate in entrepreneurship class [22 boys (52\%) and 20 girls (48\%)] with a mean age of 21.01 years from a study program of Yogyakarta State University. [39] found there was no statistically significant interaction effects were found regarding gender and the creative stimulating environment. Gender composition in a group was assumed not influence to the treatment.

This instructional treatment was conducted over 7 weeks in the second term of 2014-2015 academic year at Yogyakarta State University. The learning conducted in this research was project-based learning applying the following learning procedures; exploration, implementation, realization, presentation, and reflection. Students worked in groups of three to four individuals were obliged to attain the target of finishing projects. The students were faced with challanging question or directed by question "What kind of creative economic products can be extracted from the potential of local communities that meet criteria as creative product?" A product may be in the form of a tangible or intangible such as sketch, blue print, or prototype. A prettest was administered before the initial meeting used a scale to gather information about students' perception on current learning environment. The learning contract informed the student about the learning program through project, the target of the project, evaluation criteria, and phases of the project that should be passed. Students are equipped with guidebooks about the project, the assessment criteria, and learning modules about 14 areas of creative economy. Duration of the lessons was for 100-minute periods face to face but the students work independently along the semester.

\section{B. Procedure}

Phase I exploration; students collaboratively were explored the local potential creative economy to stimulate sense of creativity. The target was to find out some creative ideas. The SWOT analysis was conducted to select one best of top three most creative ideas. A final decision was made and the selected idea was set as project theme. Simple project plan was arranged following the guide book. Each group presented a project proposal and receive feedback from others and lecturer. The project plans were revised for a week while they were preparing idea development during implementation phase.

Phase II implementation; students developed their ideas compared with other existing products, gathered information about the competitors' comparative advantages, and they tried to create more value added on the idea being developed to be 
unique and different. During the idea development process each group made presentation about idea were being developed and received feedback from others as useful information to heighten uniquess of the idea. The implementation phase on idea development took 2 weeks up to complete. Lecturer encouraged and motivated the students to realize their ideas into more tangible products.

Phase III realization; students tried to manifest the idea in the form of either ideas, sketches, or prototypes of products. During the process the students work on collaborative situation. Students made presentation about their progress and they received input from others and lecturer. This activity took 2 weeks. Lecturer reminded the students about time limit of product realization and pushed the students to prepare next final presentation.

Phase IV presentation; final presentation conducted to perform the product. Each group presented products' uniqueness based on the predetermined criteria. Two observers employed to assess the product being displayed during the presentation process. A consensual assesment was applied to reach rate of agreement between the raters. Supportive feedback was provided to motivate students to become more creative in the future. The presentation took 3 hours of totally 8 groups, where each group was provided totally 20 minutes for presentation. Students have 10 minutes for presentation and 10 minutes left for the assesors made clarification and questioning. Lecturer conducted discussion with the students related to the project and identified about constraints. Lecturer encouraged the students to make self reflection by investigating all the inhibited factors and the supporting factors appeared during the project implementation.

Phase V reflection; students presented result of self reflection, picking lesson learn from the project. Lecturer asked the students honestly acknowledge their strengths and weaknesses and took valuable lessons learned from the project. Each group shared their experiences with other groups. A posttest was administerred at the end of the learning session for further analysis

\section{Instrument}

The instrument was designed to reveal with the following aspects as indicators; involvement and participation in the learning conducted, pattern of lecturer interaction, freedom in exploration, participation and collaboration, openness of lecturer attitude, and freedom in executing initiatives. The pilot testing using as basis test of item validity with the Pearson Product-Moment correlation coefficient analysis. The findings showed twenty-eight out of sixty items were found to be valid with a value of $r>0.361$ (i.e., $r_{\text {table }}$ ), $\alpha=0.05$, and $\mathrm{N}=$ 30. A test of reliability was applied on the twenty-eight valid items with all indicators being found to be represented in the items.

The reliability test used Cronbach's Alpha and the findings showed Cronbach's alpha coefficient of reliability for the total scale was $0.84>0.71$ (i.e., $r_{\text {table}}$ ). Finally, the twenty-eight statement items were found to be valid and reliable and represented of all the indicators. The criteria for answer scores are; $1=$ inappropriate, $2=$ moderately appropriate, $3=$ appropriate, and $4=$ very appropriate. The data were transformed into an interval scale.

\section{Data analysis}

The statistical analyses were made via SPSS 17.0. The inferential statistic method of using the paired sample t-test was employed to test the difference mean score between pretest and posttest of the group. The requirements for analysis of pretest and posttest data of the paired groups were fulfilled by means of the one sample Kolmogorov-Smirnov test of normality in data distribution and Levene's test of equality of variances (or homogeneity of variance) in data with $\mathrm{p}>0.05$. Statistical techniques such as mean $(\bar{X})$, standard deviation (Std. Dev.), and the paired sample t-test was used in the analysis of the data. The $p$ value was held as 0.05 .

\section{RESULT AND DISCUSSION}

The learning process matched with the scenario and it could provide better atmosphere. The projects assignment were complete, and product prototypes were successfully made. Freedom in exploring and actualizing caused the learning environment become more open that it was capable to encourage participation and voluntary contribution. The lecturers' roles as learning partner and facilitator was effectively work, kept reminding students about the target, and gave valuable input in weekly meetings. Through a questionnaire the students concerned gave response and $99 \%$ of them gave the impression that the learning process was beneficial because it offered the opportunity for selfactualization, it was interesting and exciting, and it gave training in having collaboration, communication, and responsibility with various parties. These students gave such natural responses as the following statement: "the lesson is enjoyable...long live the entrepreneur spirit." Each group concerned unexpectedly delivered respective slogans of their own at the end of the presentation session. They are shown such as; "to fail is something ordinary, but to get up is something extraordinary" by Hola Group, "people who are afraid to lose never experience a victory yet" by Selo Bag Group, "however great the past was, but the greater is your future" by Sabar Group," however great your problem is, still greater is God" by Citra Group, "failure is something ordinary but success is something extraordinary" by Box Hape Group, and "It is better to be poor in wealth than to be poor in knowledge and wisdom" by Meriah group.

The learning conducted ended with a posttest resulting in higher mean score so that there was a gain score of 5.44. The pre-test and the post-test achievement scores of the students in the group have been compared in Table 2. The average pretest score of the students in the group was found to be $\bar{X}$ pretest $=93.51 \pm 8.86$, and the average post-test score of the 
students in the group has been found as $\bar{X}$ post-test= $98.95 \pm 7.17$. The difference between the two observations has been analysed through paired sample t-test. The accounted tvalue has been found as $[t(40)=4.71]$. The result of analysis between the two means of observation in the group showed significantly difference between the pre-test and the post-test scores of the group in 0.05 level $[p=0.00, p<0.05]$.

TABLE 1. RESULTS OF THE PAIR SAMPLES T-TEST

\begin{tabular}{|c|c|c|c|c|c|c|c|}
\hline \multirow{2}{*}{$\eta$} & \multicolumn{2}{|c|}{$\bar{X}$} & \multicolumn{2}{c|}{ Std. Dev. } & \multirow{2}{*}{ Df } & $\mathrm{t}$ & $\mathrm{p}$ \\
\cline { 2 - 6 } & Pretest & Posttest & Pretest & Posttest & & \\
$(\eta-1)$ & & & \\
\hline 42 & 93.51 & 98.95 & 8.86 & 7.17 & & 4.71 & $0.00^{*}$ \\
\hline
\end{tabular}

It was concluded that there was statistically significant difference in students perception about the learning environment between two sets of observation. The projectbased learning were applied show effective in improving learning environment. The learning process well conducted and the projects asked for were completed indicate the dynamic activities between the groups and groups' member. Learning process occurred well it could avoid the students from formal situation and it was able to encourage students became more active. Collaboration occurred between the groups' member and they tried hard to contribute to both of the ideas creation and ideas development. There was a fair competition among groups that stimulate each group to be able to produce something unique from anything produced by any of the other groups. Each group presentation was received comments from other students' and there was no ill feeling response dealing with the comments. This situation was positive in nature to each group presentation because PBL built awareness about the important sharing of ideas among the students.

The research findings indicate that that the PBL model is potential for developing learning environment, on the other hand, there are many challenges to confront and many factors that exert influence. [40] have compared students' perceptions of the learning results of three types of entrepreneurial learning environments. The students felt that doing real-life projects was the most beneficial learning environment. According [1], it is apparent that learning within a real business environment is the key to succeed in entrepreneurial education. [20] stated that the PBL model can facilitate active, collaborative, and constructivist principles of learning that is able form a better learning environment. The PBL model has the nature of fitting these characteristics that powerfull to form creative environment. The PBL model provides opportunities for the student to immerse in the 5E's instructional model that are engage, explore, explain, extend or elaborate, and evaluate. Students could be encouraged to think more creatively. The opportunities are in the form of an environment that stimulate creativity development [41]. In line with it, the successful of the PBL model applied could be explained from some viewpoints.

The procedure of PBL model encourages each student to be actively involved in the exploration of ideas such as idea evaluation and selection, idea development, idea presentation, and idea actualization. A weekly presentation of the progress stimulated each group to perform better and tried to be the best. During the project completion i.e the ideas development phase stimulates students to make their idea look different and unique compare with any of the others. Students tried hard to seek information about their product compare with the competitor and analyzed their strength and weakness. Finally the each group was found value propositions of the product. The challenge continues when they were self motivated to actualize the idea into a more tangible product. The learning environment became more exciting because each group should be active and became the best during the presentation session. Each group presented with appreciation related to their achievement led to feel of being able to solve problems. In line with the opinion of [42], PBL is suitable for adults' education as an innovative and creative approach to solve the problem through an actual learning environment. This situation means that the environment concerned was perceived conducive to express their ideas. Students feel comfortable because constructive atmosphere appeared during development of those ideas.

We found students' opinion reflected positive attitude and indicated the level of satisfaction with context. Each student already positively perceived the learning environment is a critical condition for developing creativity. [28] stated a learning environment that already attains the level which is hoped for and perceived congruently is the critical condition for creativity development. It means that in some cases the learning environment put forth already fits students' desire but it can reach the different level of satisfaction on each student. So, we did not only investigate the gained score and the significance level of satisfaction the learning environment but we also investigated students' behavior and responses during the project. The students' behaviors and responses indicated that they express their idea freely in a constructive environment. It reflected that relation between person and environment naturally being well-matched. The process has the nature of being reciprocal and, as explained by [13], individual's behavior is a function of the individual's characteristics and the environment where an individual does his or her activities.

The project assignment in the PBL model obliged interaction with many figures such as lecturers, business people, public figures, and partners outside the circles of figures within the campus. [43] found that a factor needs to be given particular attention to is change in policy, culture, and communication. Learning environment formed in the classroom is inseparable from the macro-environment, personality, and figures of people outside the campus 
environment. Statistically the PBL model creates better learning environment but there are also many factors influence to the learning environment. PBL model was implemented not only pursue learning environment but its potential in providing outreach activities can expand the relation between the individual and the environment. The environment outside the classroom (mezzo level) and learner personality characteristics interacted with learning situation (micro level) that is condusive for creativity development.

Structured PBL model equiped with the guidebook, well designed learning material, and fair evaluation system make easy adaptation in which learners have no difficulties in completing the targeted project in accordance with the time allocation, and safeguard team cohesiveness. According to [29], though PBL is more enjoyable than traditional learning, there are still challenges related to the understanding of what a project is and the availability of the equipment required, the process of adaptation to a more structured PBL approach, the availability of guidance in each important stage of the project, and the openness of the evaluation of the individuals in a team. It means that PBL should be carefully designed. [44] proposed the term of moderate constructivism could lay the foundation for giving freedom and autonomy but a strategy should be developed. [45] argued that giving people more choice during creative problem solving may not lead to more creative outcomes. Both conditions of high prior experience and explicit instructions to be creative needed for high choice to lead to more creative performance. Explicit instructions to be creative may increase a person's effort or attempt to be creative.

Research has a restricted area of generalization for students in a study program and the results could differ for study programs differing in characteristics.

\section{CONCLUSION}

The PBL model is potential in increasing learning environment. This research also proved that PBL could bring positive gains due to student's perception on environmental beliefs. It is potential to achieve learning environment that is congruent with what the learner hopes for. The learner's perception of the learning environment should be felt as an experience that is important to be revealed in for improving the performance of the PBL model so it reaches a level which is congruent between the hopes of the individuals and the environment enveloping them. Despite the fact that socioeconomic conditions, gender and culture influence students' learning, PBL can play a role in creating a positive classroom environment and enhancing the creativity of students

\section{ACKNOWLEDGMENT}

The paper is written based on the research which has been done because of the financial support from (Direktorat Jenderal Pendidikan Tinggi 'Directorate General of Higher Education') and Kemenristek (Kementerian Riset dan Teknologi 'Ministry of Research and Technology'). The writer also thanks UNS (Universitas Sebelas Maret 'University of Sebelas Maret') and UNY (Universitas Negeri Yogyakarta 'State University of Yogyakarta') for having cooperatively given the facilities and opportunity for the research

\section{REFERENCES}

[1] VP. Taatila (2010). Learning entrepreneurship in higher education. Education \& Training Journal, vol. 52, pp. 48-61, 2010.

[2] A. Lautenschläger \& JH. Haase, "The myth of entrepreneurship education: seven arguments against teaching business creation at universities" Journal of Entrepreneurship Education, Vol. 14, pp. 147$161,2011$.

[3] C. Hartshorn and P.D. Hannon, "Paradoxes in entrepreneurship education: chalk and talk or chalk and cheese? A case approach". Journal of Education \& Training Vol. 47, 8/9, pp.616-627, 2005.

[4] I. Susnea, and A. Tataru, A. "Fostering creativity through education - key factors, and action directions". Research and Science Today, Vol. 1, (7), pp. 194-202, 2014.

[5] C. Holmgren, J. From, A. Olofsson, H. Karlsson, K. Snyder. and U. Sundström, Entrepreneurship education: salvation or damnation?" International Journal of Entrepreneurship, Vol. 8, pp. 55-71, 2004.

[6] D.A, Kirby, "Entrepreneurship education: can business schools meet the challenge?" Education \& Training Journal, 46, 8/9, pp. 510-519, 2004

[7] M. Abduh, A. Maritz, and S. Rush, "An evaluation of the enterpreneurship education in Indonesia: A case study of Bengkulu University". The International Journal of Organizational Innovation, vol. 4,(4), pp. 21-47, 2011.

[8] S. Bell, "Project-based learning for the 21st century: skills for the future". The Clearing House, vol. 83, pp. 39-43, 2010

[9] J.W. Thomas. A review of research on project-based learning executive summary. San Rafael, CA: The Autodesk Foundation, 2000.

[10]. T.M. Amabile, "Attributions of creativity: What are the consequences?" Creativity Research Journal, vol. 8, pp. 423-426, 1995.

[11]. Munandar (2009). Pengembangan kreativitas anak berbakat (3rd ed.) Jakarta: Rineka Cipta (Teks in Indonesia language)

[12]. S. Yang and Y. Zhong, "Analysis of the factors that influenced on team creativity in product conception design stage". Applied Mechanics and Materials Journal, vol 101,(102), pp. 96-99, 2012.

[13]. S. Jelena, T. Leona and T. Vivian, "Employer-employee congruence in environmental values: an exploration of effects on job satisfaction and creativity". Journal of Business Ethics, vol. 130 (1), pp. 117-130, 2015.

[14]. AY. Kristof-Brown and RP. Guay, "Person-environment fit". In S Zedeck (Ed.) APA handbook of industrial and organizational psychology vol. III,. Washington, DC: American Psychological Association, 2011, pp. 3-50.

[15]. K.C. Tsai. "The interplay between culture and creativity". CrossCultural Communication Journal, vol 8 (2), pp. 15-20, 2012

[16]. M. Rhodes, An analysis of creativity. In frontiers of creativity research: Beyond the basics, ed. SG Isaksen, New York: Bearly, 1961/1987, pp. 216-22.

[17] D. Hasirci and H. Demirkan, "Creativity in learning environments: The case of two sixth grade art-rooms. The Journal of Creative Behavior, vol. 37 , pp. $17-41,2003$

[18] T.M. Amabile and R. Conti, "Changes in the work environment for creativity during downsizing". Academy of Management Journal, vol. 42.(6), pp. 630-640, 1999 
[19] M. Batey \& A. Furnham, "Creativity, intelligence and personality: A critical review of the scattered literature. Genetic, Social, and General Psychology Monographs, 132, pp. 355-429, 2006

[20] K. Sawyer, "A call to action: the challenges of creative teaching and learning". Teachers College Record, vol 117 (10), pp. 1-34, 2015

[21] K.P. Dickinson, S. Soukamneuth, H.C. Yu, M. Kimball, R. D‘Amico, and R. Perry, "Providing educational services in the summer youth employment and training program (technical assistance guide). Washington, DC: U.S. Department of Labor, Office of Policy and Research, 1998 .

[22] J.W. Thomas, J.R. Mergendoller, J. R. and A. Michaelson, Project-based learning: A handbook for middle and high school teachers. Novato, CA: The Buck Institute for Education, 1999.

[23] P. Blumenfeld, E. Soloway, R. Marx, J. Krajcik, M. Guzdial. and A. Palincsar, "Motivating project-based learning: Sustaining the doing, supporting the learning" Educational Psychologist, vol. 26 (3-4), pp. 369-398, 1991

[24] D. Moursund, Project-based learning using information technology. Eugene, Oregon: International Society for Technology in Education, 1999.

[25] J. Burbiel, "Creativity in research and development environments: A practical review". Int. Journal of Business Science and Applied Management, vol. 4(2), pp. 35-51, 2009.

[26] M. Wena, Strategi pembelajaran inovatif kontemporer: suatu tinjauan konseptual operasional. Jakarta: Bumi Aksara (Text in Indonesian language, 2009.

[27] K. Thomson and B. Joel, "The leadership book: enhancing the theorypractice connection through project based learning". Journal of Management Education, vol. 31, (2), pp. 278-292, 2007.

[28] J.N. Choi, "Person-environment fit and creative behavior: Differential impacts of fit". Human Relations, vol. 57(5), pp. 531-552, 2004.

[29] D. O'Sullivan and F. Krewer, "Structured approach to project based learning using a new type of learning management system. European Conference on e-Learning: 460-XVII. Kidmore End: Academic Conferences International Limited, Oct. 2015.

[30] M. Gültekin, M, "The effects of project-based learning on learning outcomes in the 5 th grade social studies course in primary education. Educational Sciences: Theory and Practice, vol. 5(2), pp. 548-556, 2005.

[31] J. Wilhelm, S. Sherrod, and K. Walters, "Project based learning environments: challenging preservice teachers to act in the moment" Journal of Education Research, vol. 101,(4), pp. 220-233, 2008.

[32] HL. Yang and HH. Cheng, "Creativity of student information system projects: From the perspective of network embeddedness. Computers \& Education, vol. 54(1), pp. 209-221, 2010

[33] S. Wurdinger \& M. Qureshi, "Enhancing college students' life skills through project based learning" Innovative Higher Education, vol. 40(3), pp. 279-286, 2015

[34] M. Munakata \& A. Vaidya, "Using project-and theme-based learning to encourage creativity in science. Journal of College Science Teaching, vol. 45 (2), pp. 48-53, 2015

[35] G. Bas, "Investigating the effects of project-based learning on students' academic achievement and attitudes towards english lesson" TOJNED : The Online Journal Of New Horizons In Education, vol. 1 (4), pp. 1-15, 2011

[36] A. Collins, J.S. Brown and S.E. Newman, "Cognitive apprenticeship : Teaching the crafts of reading, writing, and mathematics, in L.B. Resnick (Ed.), Knowing, Learning, and Instruction: Essays in Honor of Robert Glaser, Hillsdale, NJ, Lawrence Erlbaum Associates, p. 453-494, 1989.

[37] A. Kerne, A.M. Webb, M. Andrew, C. Latulipe, E. Carroll, S. Drucker, M. Steven, C. Linda and K. Hook, "Evaluation methods for creativity support environments. Paper presented at Proceedings of CHI 2013 Conference on Human Factors in Computing, Paris, France, April 27 May 2, 2013,

[39] S. Garces and M. Pocinho, "The impact of the creative environment on the creative person, process, and product. Avaliação Psicológica, vol. 15(2), pp. 169-176, 2016

[38] D. Scott and R. Usher, Researching education: Data methods and theory in educational inquiry, 2nd edition. London: Continuum, 2011

[40] S. Hanti, L. Kairisto-Mertanen, J. Kallio-Gerlander, and H. Rantanen, "Identifying entrepreneurial competences in three different crossdisciplinary environments", in Ingle, S. and Neuvonen-Rauhala, M. (Eds), promoting entrepreneurship by Universities. [The Proceedings of the 2nd International FINPIN 2008 Conference, Ha" meenlinna, Finland, April 20-22, pp. 299-306, 2008]

[41] BB. Akcay, "Entomology: promoting creativity in the science" Lab .Science Activities, vol. 50 (2), pp. 49-53, 2013

[42] M. Muresan, "Project based collaborative learning for adult education" The International Scientific Conference eLearning and Software for Education (3), pp. 303-309, 2014

[43] P. Rojanapanich and N. Pimpa, "Creative education, globalization and social imaginary". Creative Education Journal, vol. 2, (4), pp. 327-332, 2011,

[44] E. Terhart, "Konstruktivismus und Unterricht. In: Zeitschrift für Pädagogik, vol. 5, pp. $629-647,1999$.

[45] A. Pera, "Contemporary readings in law and social justice, vol. 5(2), pp. $158-163,2013$ 